\title{
Source tracking of Shiga-like toxin-producing Escherichia coli in the fresh vegetable production system of South India
}

\author{
Periasamy Pushpakanth ${ }^{1} \cdot$ Zachariah John Kennedy $^{2} \cdot$ Dananjeyan Balachandar $^{1}$ (I)
}

Received: 1 November 2018 / Accepted: 29 April 2019 / Published online: 15 May 2019

(C) Università degli studi di Milano 2019

\begin{abstract}
Purpose Numerous outbreaks of foodborne diseases through fresh agricultural produce urge research to assess the source of entry of pathogens to the produce that compromise microbiological safety. In the present investigation, the entry of shiga-like toxin-producing Escherichia coli $\mathrm{O} 157: \mathrm{H7}$ in a fresh vegetable production system was assessed by microbiological and molecular approaches.

Methods Five major vegetables, viz., beetroot, cabbage, carrot, onion, parsley, and potato, being cultivated routinely in the Western Guats of South India (The Nilgiris), were assessed for the prevalence of E. coli O157:H7. The fresh produce, rhizosphere soil, and water resources were sampled and the total coliforms and E. coli counts were assessed by plate count method and the O157:H7 by polymerase chain reaction targeting shiga-like toxin gene (stx1).

Results The results revealed that all the vegetables collected from the fields had high levels of total coliforms ( $3 \log$ CFU per g) with high proportions of $E$. coli (1-2 log CFU per g). The prevalence of O157:H7 among the E. coli isolates in these vegetables ranged from 0 to $5.8 \%$. However, the prevalence of $\mathrm{O} 157: \mathrm{H} 7$ in rhizosphere soil of these vegetables was relatively high (1.6 to $42.5 \%$ ). The water used for irrigation and washing the produce (carrot) also showed the presence of O157:H7. The real-time quantitative PCR (qPCR)-based detection of stx 1 revealed that the O157:H7 prevalence in these vegetables and their rhizosphere soil were in higher magnitude than the counts by culturable method. The rhizosphere soil and water samples had higher O157:H7 CFU equivalents than fresh produce.

Conclusions It is evident that the soil as well as the irrigation and process water got contaminated with feces, which are assumed to be the primary source and cause for the entry of $\mathrm{O} 157: \mathrm{H} 7$ to the fresh vegetable. Hence, good agronomical practices and good hygiene post-harvest practices have to be imposed in the vegetable production system to avoid the pathogen entry.
\end{abstract}

Keywords Fresh produce $\cdot$ E. coli $\mathrm{O} 157: \mathrm{H} 7 \cdot$ Irrigation water $\cdot$ Rhizosphere $\cdot$ stxl gene $\cdot$ Real-time PCR

\section{Introduction}

Foodborne diseases, caused by the consumption of food contaminated by bacteria, virus, or chemicals, are the major health burden worldwide with increased morbidity and mortality (Kennedy et al. 2004). A review on foodborne outbreaks in India from 1980 to 2016 showed that important microbial pathogens such as Staphylococcus aureus, Vibrio sp.,

Dananjeyan Balachandar

dbalu@tnau.ac.in

1 Department of Agricultural Microbiology, Tamil Nadu Agricultural University, Coimbatore 641003, India

2 Post Harvest Technology Centre, Tamil Nadu Agricultural University, Coimbatore 641003, India
Salmonella sp., Escherichia coli, Yersinia enterocolitica, and Norwalk-like virus were responsible for foodborne illnesses (CDC 2018). However, bacterial contamination remains to be the most important source, among which $E$. coli $\mathrm{O} 157: \mathrm{H} 7$ is the leading causative agents with $20 \%$ of foodborne-related diseases, next to Salmonella sp. (Olsen et al. 2000; Su and Li 2005). Escherichia coli O157:H7 is an enterohemorrhagic Shiga toxin-producing foodborne pathogen causing bloody diarrhea, which may progress to the serious complication known as the hemolytic uremic syndrome that leads to severe illness or even death (Karmali 2004).

Fresh vegetables are considered to be an important source of nutritious and healthy diet in many parts of countries. India is the second largest producer of vegetables accounting for $10 \%$ of total global production with an annual production of 168.6 million tonnes in an area of 9.6 million ha (NHB 2017). The diverse agro-climatic 
condition, consumers' demand, variety, and availability throughout the year favor the cultivation of almost all types of vegetables. The national nutrition guidelines recommend the average vegetable consumption of $300 \mathrm{~g}$ per person per day (NIN 2011). Hence, the demand for fresh vegetables has increased nowadays with concern for healthy lifestyle and balanced diet (Olaimat and Holley 2012). In the past few years, outbreaks caused by consumption of fresh vegetables have increased in developing countries (Söderström et al. 2008; Wendel et al. 2009; Denis et al. 2016; Gutiérrez-Rodríguez et al. 2019). Cattles are the most important reservoir for E. coli O157:H7, followed by deer, goats, horses, dogs, and pigs (Smith and Fratamico 2005). However, fresh produce has become the second most important vehicle of transmission associated to E. coli O157:H7 outbreak (Julien-Javaux et al. 2019). Therefore, control and prevention of these pathogens using quick and precise detection methods are required for the food industry (O'Grady et al. 2009).

Routine identification and enumeration of $E$. coli in food sample by traditional methods are laborious and time consuming, and sometimes may lead to unpredicted results (Malorny et al. 2003). The PCR-based detection methods have become the valuable and effective tool to detect pathogenic bacteria in different food matrices (Hines 2000) because of their rapid and accurate results. This is mainly essential for fresh-cut vegetables due to their perishable nature. Real-time quantitative PCR (qPCR) is being used as a diagnostic test in the food analysis as an automated highthroughput technique which allows quantification without post-PCR manipulation and with low risk of crosscontamination (Mackay 2004; Mckillip and Drake 2004). Currently, several genes have been used as targets for molecular detection of E. coli O157:H7 (Delannoy et al. 2013; Franz et al. 2014) such as Shiga toxin 1 (stxl) and Shiga toxin 2 (stx2) which are the most critical virulence factors. PCR assays targeting these genes have been developed (Fode-Vaughan et al. 2003). Ibekwe et al. (2004) quantified the natural E. coli $\mathrm{O} 157: \mathrm{H} 7$ using multiplex qPCR from phyllosphere and rhizosphere of lettuce. The prevalence of E. coli $\mathrm{O} 157: \mathrm{H} 7$ in animal products (Heredia and García 2018) and raw vegetables (Kim et al. 2014; Cardamone et al. 2015; Denis et al. 2016; Alegbeleye et al. 2018) are well documented.

Therefore, the present survey aimed to identify the prevalence and persistence of pathogenic E. coli $\mathrm{O} 157: \mathrm{H} 7$ in fresh vegetables and also to explore rapid molecular tools for the effective risk assessment of foodborne outbreaks. We integrated conventional enumeration technique with $\mathrm{qPCR}$, in order to explore the sensitivity, reliability, and quickness of both methods. Therefore, this investigation is of importance as it would contribute to the understanding of the epidemiology of the infection caused by E. coli $\mathrm{O} 157: \mathrm{H} 7$ pathogen from agricultural produces.

\section{Materials and methods}

\section{Bacterial strain}

Escherichia coli $\mathrm{O} 157: \mathrm{H} 7$ strain which was isolated from contaminated irrigation water in Tamil Nadu Agricultural University, Coimbatore, and characterized for the presence of both stxl and stx2 (Shiga-like toxin-producing genes), eae (intimin-producing gene) which was designated as O157TNAU was used as reference strain in this present study (Naganandhini et al. 2015).

\section{Study area and sampling}

In the course of this study, five vegetable-growing areas were investigated during March 2018. The chosen areas are located in five neighborhoods in the Kookalthorai region of Ooty, Tamil Nadu, situated at a latitude of $11.49^{\circ} \mathrm{N}$ and longitude of $76.83^{\circ} \mathrm{E}$ with an annual average rainfall of $1920.8 \mathrm{~mm}$. The crops in those areas have been produced for more than 20 years. The fresh vegetables, viz., beetroot (Beta vulgaris), cabbage (Brassica oleracea), carrot (Daucus carota), onion (Allium cepa), parsley (Petroselinum crispum), and potato (Solanum tuberosum), and their respective rhizosphere soils along with irrigation water sources were randomly collected for possible isolation of $E$. coli $\mathrm{O} 157: \mathrm{H} 7$. The samples of vegetables were placed in the sterile bags (HiMedia, India) and the rhizosphere soil samples were collected by removing loosely held soil on the roots, into the stomacher bags. The water samples were collected using sterile screw-capped 250-mL glass bottles. All the collected samples were transported under a chilled condition to the Department of Agricultural Microbiology laboratory of the institute and analyses were commenced within $24 \mathrm{~h}$ of sample collection.

\section{Physicochemical properties of the rhizosphere soil}

The physicochemical properties of rhizosphere soil are presented in Table 1. Soil $\mathrm{pH}$ and electrical conductivity (EC) were estimated using a glass electrode with a soil to water ratio of 1:2. The microbial biomass carbon (MBC) was estimated by the fumigation-extraction method (Jenkinson and Ladd 1981). Dehydrogenase (EC 1.1.1.1) was quantified by the reduction of triphenyl tetrazolium chloride to triphenyl formazan (TPF) and expressed in $\mu \mathrm{g}$ of TPF released per $\mathrm{g}$ soil per day (Klein et al. 1971).

\section{Bacteriological analysis}

For enumerating E. coli, Petrifilm EC ( $3 \mathrm{M}^{\mathrm{TM}}$ Petrifilm ${ }^{\mathrm{TM}} \mathrm{EC}$, St. Paul, MN, USA) was used by following the manufacturer's instructions. Briefly, $25 \mathrm{~g}$ of each vegetable sample was enriched with $225 \mathrm{~mL}$ of peptone broth in Baglight ${ }^{\circledR}$ sterile 
Table 1 Physicochemical properties of rhizosphere soil collected from farmers` fields

\begin{tabular}{lllll}
\hline Vegetables & $\mathrm{pH}$ & $\mathrm{EC}(\mathrm{dS} / \mathrm{m})$ & $\begin{array}{l}\text { Dehydrogenase } \\
(\mu \mathrm{g} \text { TPF released per g soil per day })\end{array}$ & $\begin{array}{l}\text { Soil biomass carbon } \\
(\mu \mathrm{g} / \mathrm{g})\end{array}$ \\
\hline Parsley & $6.05( \pm 0.17)^{\mathrm{ab}}$ & $0.24( \pm 0.03)^{\mathrm{ab}}$ & $6.27( \pm 0.21)^{\mathrm{a}}$ & $570.0( \pm 75.0)^{\mathrm{ab}}$ \\
Potato & $5.46( \pm 0.03)^{\mathrm{b}}$ & $0.48( \pm 0.01)^{\mathrm{a}}$ & $5.59( \pm 0.74)^{\mathrm{ab}}$ & $675.0( \pm 68.7)^{\mathrm{a}}$ \\
Beetroot & $6.44( \pm 0.09)^{\mathrm{a}}$ & $0.13( \pm 0.02)^{\mathrm{b}}$ & $4.82( \pm 0.57)^{\mathrm{ab}}$ & $405.0( \pm 68.7)^{\mathrm{b}}$ \\
Cabbage & $5.71( \pm 0.22)^{\mathrm{ab}}$ & $0.34( \pm 0.14)^{\mathrm{ab}}$ & $1.23( \pm 0.17)^{\mathrm{c}}$ & $585.0( \pm 90.0)^{\mathrm{ab}}$ \\
Carrot & $5.76( \pm 0.51)^{\mathrm{ab}}$ & $0.28( \pm 0.14)^{\mathrm{ab}}$ & $4.27( \pm 0.31)^{\mathrm{b}}$ & $525.0( \pm 79.4)^{\mathrm{ab}}$ \\
\hline
\end{tabular}

Values are mean $( \pm \mathrm{SE})(n=3)$ and within each column, values followed by the same letters are not significantly different from each other according to DMRT $(p \leq 0.05)$ bags (Interscience, France) in Class-II Biological safety cabinet (Nuaire, USA). Then the samples were homogenized using a stomacher (BagMixer®, Interscience, France) at $230 \mathrm{~min}^{-1}$ for $2 \mathrm{~min}$. For rhizosphere soil, $1 \mathrm{~g}$ of respective samples was serially diluted in peptone water and a volume of $1 \mathrm{~mL}$ of the appropriate dilutions was placed on the Petrifilm and incubated at $37^{\circ} \mathrm{C}$ for $24 \mathrm{~h}$. Total coliforms and E. coli colonies were enumerated and the results were expressed as log colony-forming units (CFU) per $\mathrm{g}$ or $\mathrm{mL}$ of sample. On Petrifilm EC plates, total coliforms were calculated by counting blue and red colonies with and without gas production, in which red and blue colonies with gas production were counted as typical E. coli.

\section{DNA extraction}

An aliquot of $200 \mu \mathrm{L}$ of suspension from the bagmix was added with $100 \mu \mathrm{L}$ of Sephadex ${ }^{\circledR}$ G100 (Sigma-Aldrich, St Louis, USA) (10\% Sephadex ${ }^{\circledR}$ G100 in $100 \mathrm{mM}$ Tris, $1 \mathrm{mM}$ EDTA, $100 \mathrm{mM} \mathrm{NaCl}$ ), vortexed for $20 \mathrm{~s}$, and incubated at $95{ }^{\circ} \mathrm{C}$ for $20 \mathrm{~min}$ with intermittent vortexing. After centrifugation at $12000 \mathrm{~g}$ at room temperature for $3 \mathrm{~min}$, an aliquot of $100 \mu \mathrm{L}$ supernatant was transferred to a new tube and from that $1 \mu \mathrm{L}$ was used as a template for PCR. Soil DNA was extracted using Fast-DNA ${ }^{\mathrm{TM}}$ Spin Kit for Soil (MP Biomedicals, Ohio, US) from $500 \mathrm{mg}$ of soil, following the manufacturer's specifications. All the extracted DNA were quantified spectrophotometrically (Nanodrop 2000, Thermo Scientific, USA), adjusted to $20 \mathrm{ng} / \mu \mathrm{L}$ working stocks and stored at $-20{ }^{\circ} \mathrm{C}$.

\section{Colony PCR for detection of 0157}

A total of 1149 E. coli isolates from vegetable, rhizosphere, and farm source were analyzed for detection of Shiga-like toxin-producing $E$. coli (STEC) by PCR targeting the stx 1 gene. The amplification was carried out using stx 1 primers (Forward 5'- CAGTTAATGTGGTGGCGAAGG -3' and reverse 5'-CACCAGACAATGTAACCGCTG-3') (Cebula et al. 1995). The $10 \mu \mathrm{l}$ PCR reaction mixture contained $1 \times$ Taq buffer with $2.5 \mathrm{mM} \mathrm{MgCl}_{2}, 200 \mu \mathrm{M}$ of each deoxynucleoside 5-triphosphate, $1 \mu \mathrm{M}$ of each primer, and $2 \mathrm{U}$ of Taq DNA polymerase (HiMedia, India) were adjusted to a total volume with sterile deionized water. Approximately, colonies of $1 \mathrm{~mm}$ in diameter were picked up with a sterile toothpick and directly mixed to a PCR tube as a template. PCR amplification was performed in a thermal cycler (Applied Biosystem, USA) with the following conditions: initial denaturation at $95{ }^{\circ} \mathrm{C}$ for $10 \mathrm{~min}$, followed by 35 cycles of $94{ }^{\circ} \mathrm{C}$ for $1 \mathrm{~min}$ (denaturation), $55{ }^{\circ} \mathrm{C}$ for $1 \mathrm{~min}$ (annealing), $72{ }^{\circ} \mathrm{C}$ for $1 \mathrm{~min}$ (primer extension), and a final extension step of $72{ }^{\circ} \mathrm{C}$ for $10 \mathrm{~min}$. The PCR products were analyzed by electrophoresis on $1.5 \%$ agarose gel stained with ethidium bromide, visualized, and documented using gel document and analysis system (Syngene, UK). The E coli O157-TNAU was used as positive control (Naganandhini et al. 2015).

\section{qPCR analysis}

All extracted DNA samples (vegetables, water, and soil) were quantified for STEC by qPCR targeting stx1. Quantification was performed in Roche Lightcycler®480II (Roche, Switzerland) in a reaction mixture of $10 \mu \mathrm{L}$ containing $0.5 \mu \mathrm{M}$ primer; $5 \mu \mathrm{L}$ of Lightcycler® 480II SYBR Green I Master mix; and $1 \mu \mathrm{L}$ of template DNA. PCR was started at $95{ }^{\circ} \mathrm{C}$ for $10 \mathrm{~min}$, followed by 40 cycles of denaturation at $94{ }^{\circ} \mathrm{C}$ for $20 \mathrm{~s}$, primer annealing at $65{ }^{\circ} \mathrm{C}$ for $20 \mathrm{~s}$, and extension at $72{ }^{\circ} \mathrm{C}$ for $20 \mathrm{~s}$. Fluorescent data collection and data analysis were carried out according to the manufacturer's instructions. $C_{\mathrm{T}}$, the number of PCR cycles necessary to reach the threshold fluorescence level, was automatically determined for each sample by the software provided with the thermocycler based on the second derivative maximum method. A standard curve was generated by plotting the $C_{\mathrm{T}}$ number against $\log$ CFU of O157-TNAU for the three independent replicates, using LightCycler Software v.1 (Roche Applied Science). Amplification efficiency $(E)$ was calculated from the slope of the standard curve using the formula $E$ $(\%)=\left(10^{-1 / \text { slope }}-1\right) \times 100$. Amplification specificity was assessed by melting curve analysis of the PCR products 
automatically by the thermocycler and the presence of single DNA band of expected size after agarose gel electrophoresis $(1.5 \%)$. Quantification of gene copies per $\mu \mathrm{L}$ was done by the software provided with the instrument and expressed as CFU equivalents per $\mathrm{mL}$ or $\mathrm{g}$ of sample.

\section{Statistical analysis}

All the data were subjected to statistical analysis with software Microsoft Excel for Windows 2007 add-ins with XLSTAT version 2010.5.05 (XLSTAT 2010). Statistically significant differences between soil samples and E. coli strains were analyzed using one-way analysis of variance (ANOVA) and Duncan's multiple range test (DMRT) at 5\% significance level.

\section{Results}

\section{Physicochemical properties of rhizosphere soil}

The physicochemical properties of different rhizosphere soils were significant different among the samples. The $\mathrm{pH}$ of soils was slightly acidic (between 5.46 and 6.44) and electrical conductivity varied from $0.13 \mathrm{dS} / \mathrm{m}$ (beetroot) to $0.48 \mathrm{dS} / \mathrm{m}$ (potato). The dehydrogenase activity and soil microbial biomass carbon were higher in parsley $(6.27 \mu \mathrm{g} / \mathrm{g})$ and potato $(675.0 \mu \mathrm{g} / \mathrm{g})$ soils respectively as compared to other vegetables (Table 1).

\section{The prevalence of total coliforms and $E$. coli}

Among the five fresh vegetables targeted, carrot and cabbage had highest total coliforms (2.90 and $2.86 \log \mathrm{CFU} / \mathrm{g}$, respectively) and $E$. coli (2.06 and $1.96 \log \mathrm{CFU} / \mathrm{g}$, respectively), followed by beetroot (2.12 and 0.89 ). The potato had $1.96 \mathrm{log}$ CFU of total coliforms with $1.08 \log$ CFU of E. coli (Table 2). Among the five vegetables, parsley had less coliforms with no E. coli cells on the surface.

Table 2 The prevalence of total coliforms and E. coli in fresh vegetables under field grown conditions

\begin{tabular}{lll}
\hline Vegetables & Total coliforms $(\log$ CFU/g) & E. coli $(\log$ CFU/g) \\
\hline Parsley & $0.44( \pm 0.07)^{\mathrm{c}}$ & $0.00( \pm 0.00)^{\mathrm{d}}$ \\
Potato & $1.96( \pm 0.07)^{\mathrm{b}}$ & $1.08( \pm 0.08)^{\mathrm{b}}$ \\
Beetroot & $2.12( \pm 0.20)^{\mathrm{b}}$ & $0.86( \pm 0.06)^{\mathrm{c}}$ \\
Cabbage & $2.86( \pm 0.12)^{\mathrm{a}}$ & $1.96( \pm 0.08)^{\mathrm{a}}$ \\
Carrot & $2.90( \pm 0.10)^{\mathrm{a}}$ & $2.06( \pm 0.00)^{\mathrm{a}}$ \\
\hline
\end{tabular}

Values are mean $( \pm \mathrm{SE})(n=3)$ and within each column, values followed by the same letters are not significantly different from each other according to DMRT $(p \leq 0.05)$
Compared to vegetables, the rhizosphere soil had a higher population of total coliforms and E. coli in all the samples. Among the rhizosphere soils, beetroot, carrot, cabbage, and potato had at par levels of total coliforms (5.36 to $4.27 \mathrm{log}$ $\mathrm{CFU} / \mathrm{g}$ ), but significantly differed levels of $E$. coli counts. Carrot had $4.45 \log$ CFU/g, followed by beetroot (4.34 log CFU), parsley (4.02 log CFU), cabbage (2.99 log CFU), and potato (2.42 log CFU) (Table 3).

\section{Prevalence of $E$. coli 0157:H7 in vegetable and rhizosphere soil samples}

The colony-PCR-based identification of O157:H7 among the isolated E. coli from vegetable - and rhizosphere samples also revealed that rhizosphere soil harbored a higher number of O157:H7 than vegetable samples (Table 4). Among the five vegetables, the percent prevalence of $\mathrm{O} 157: \mathrm{H} 7$ was highest in beetroot $(5.8 \%)$ followed by cabbage (1.5\%). Least proportion of O157:H7 of 0.9\% was reported in carrot samples. In parsley, we could not isolate $E$. coli, hence could not perform the PCR screening for O157:H7 identification. However, the rhizosphere soil of parsley had maximum O157:H7 prevalence (42.5\%) compared to other vegetables. The rhizosphere soil of carrot had $13.3 \%$ O157:H7 followed by beetroot (12.5\%), while least ratio of $\mathrm{O} 157: \mathrm{H} 7$ was reported in potato rhizosphere $(2.7 \%)$ followed by cabbage $(1.6 \%)$.

\section{The prevalence of total coliforms, Escherichia coli, and Escherichia coli 0157:H7 from the water source}

The irrigation water and process water used for carrot washing after harvest had about less than 100 colonies per $\mathrm{mL}$ of total coliforms and few colonies of E. coli (Table 5). These water samples had $7.7 \%$ and $6.1 \%$ of $0157: \mathrm{H} 7$ respectively. However, the water collected after wash (at two different spots) had threefold increased total coliforms (3.54 and 3.07 log CFU/ $\mathrm{ml}$ ) with an $\mathrm{O} 157: \mathrm{H} 7$ prevalence of $10 \%$ and $8.3 \%$, respectively.

Table 3 The prevalence of total coliforms and E. coli in rhizosphere soil under field grown conditions

\begin{tabular}{lll}
\hline Vegetables & $\begin{array}{l}\text { Total coliforms } \\
(\log \text { CFU/g soil) }\end{array}$ & $\begin{array}{l}\text { E. coli } \\
(\log \text { CFU/g soil) }\end{array}$ \\
\hline Parsley & $2.42( \pm 1.26)^{\mathrm{b}}$ & $4.05( \pm 0.18)^{\mathrm{a}}$ \\
Potato & $4.27( \pm 0.11)^{\mathrm{ab}}$ & $2.42( \pm 1.21)^{\mathrm{b}}$ \\
Beetroot & $5.36( \pm 0.34)^{\mathrm{a}}$ & $4.34( \pm 0.20)^{\mathrm{a}}$ \\
Cabbage & $4.27( \pm 0.49)^{\mathrm{ab}}$ & $2.99( \pm 1.50)^{\mathrm{b}}$ \\
Carrot & $4.29( \pm 0.67)^{\mathrm{ab}}$ & $4.45( \pm 0.11)^{\mathrm{a}}$ \\
\hline
\end{tabular}

Values are mean $( \pm \mathrm{SE})(n=3)$ and within each column, values followed by the same letters are not significantly different from each other according to DMRT $(p \leq 0.05)$ 
Table 4 Presence of E. coli O157:H7 in fresh vegetables and rhizosphere soil collected from farmers' field

\begin{tabular}{|c|c|c|c|c|c|c|}
\hline \multirow[t]{2}{*}{ Vegetables } & \multicolumn{3}{|l|}{ Vegetable } & \multicolumn{3}{|l|}{ Rhizosphere soil } \\
\hline & Total E. coli isolates & $\begin{array}{l}\text { Positive for } \\
\text { E.coli O157:H7 }\end{array}$ & $\begin{array}{l}\text { The prevalence } \\
\text { of O157:H7 (\%) }\end{array}$ & Total E. coli isolates & $\begin{array}{l}\text { Positive for } \\
\text { E.coli } 0157: H 7\end{array}$ & $\begin{array}{l}\text { The prevalence } \\
\text { of } 0157: \mathrm{H} 7(\%)\end{array}$ \\
\hline Parsley & - & - & - & 40 & 17 & 42.5 \\
\hline Potato & 104 & 2 & 1.9 & 72 & 2 & 2.7 \\
\hline Beetroot & 88 & 5 & 5.8 & 80 & 10 & 12.5 \\
\hline Cabbage & 127 & 2 & 1.5 & 62 & 1 & 1.6 \\
\hline Carrot & 101 & 1 & 0.9 & 90 & 12 & 13.3 \\
\hline
\end{tabular}

Table 5 The prevalence of total coliforms, E. coli, and the presence of E. coli O157:H7 from the water sources

\begin{tabular}{lllllr}
\hline Water sources & $\begin{array}{l}\text { Total coliforms } \\
(\log \text { CFU } / \mathrm{ml})\end{array}$ & $\begin{array}{l}\text { E. coli } \\
(\log \text { CFU/ml })\end{array}$ & $\begin{array}{l}\text { Total E. coli } \\
\text { isolates }\end{array}$ & $\begin{array}{l}\text { Positive for } \\
\text { E.coli O157:H7 }\end{array}$ & $\begin{array}{l}\text { Occurrence } \\
\text { of O157:H7 (\%) }\end{array}$ \\
\hline Carrot washing I & $3.54( \pm 0.02)^{\mathrm{a}}$ & $3.38( \pm 0.04)^{\mathrm{a}}$ & 80 & 8 & 10.0 \\
Carrot washing II & $3.07( \pm 0.20)^{\mathrm{b}}$ & $2.75( \pm 0.20)^{\mathrm{a}}$ & 60 & 5 & 8.3 \\
Before wash & $1.61( \pm 0.04)^{\mathrm{c}}$ & $0.51( \pm 0.02)^{\mathrm{b}}$ & 49 & 3 & 6.1 \\
Irrigation water & $1.61( \pm 0.11)^{\mathrm{c}}$ & $0.23( \pm 0.05)^{\mathrm{b}}$ & 26 & 2 & 7.7 \\
\hline
\end{tabular}

Values are mean $( \pm \mathrm{SE})(n=3)$ and within each column, values followed by the same letters are not significantly different from each other according to DMRT $(p \leq 0.05)$

\section{Quantification of E. coli 0157:H7 by qPCR}

The qPCR directly quantified the O157:H7 in fresh vegetables collected from the field, rhizosphere soils of those vegetables, and irrigation and process water samples of carrot using the standard curve established after adding DNA from different cell loads ( 3 to $7 \log \mathrm{CFU} / \mathrm{ml}$ ). The $R^{2}$ value of 0.996 was found after regression analysis between CFU per $\mathrm{mL}$ and $\mathrm{C}_{T}$ from qPCR (Fig. 1a). The mean amplification efficiencies of qPCR assay for vegetable, rhizosphere soil, and water samples were $92 \%, 122 \%$, and $119 \%$, respectively. The melt curve analysis of all the samples used in qPCR suggested that there is only one product in the reaction (Fig. 1b). Among the five, potato and beetroot had relatively high O157:H7 (1.94 and $1.71 \log \mathrm{CFU}$ equivalents/g), while the carrot, cabbage, and parsley had at par levels (1.04 to $1.21 \log$ CFU equivalents) (Fig. 2a). However, the rhizosphere soils of these five vegetables had relatively higher CFU equivalents than their respective vegetables (ranged 2.11 to $2.68 \log$ CFU equivalents per g) with insignificant difference among them (Fig. 2b). The irrigation water used for carrot had $4.47 \log \mathrm{CFU}$ equivalents, while the wash water before and after also had a range of O157:H7 from 4.29 to $4.65 \log \mathrm{CFU}$ equivalents per $\mathrm{mL}$ (Fig. 2c).
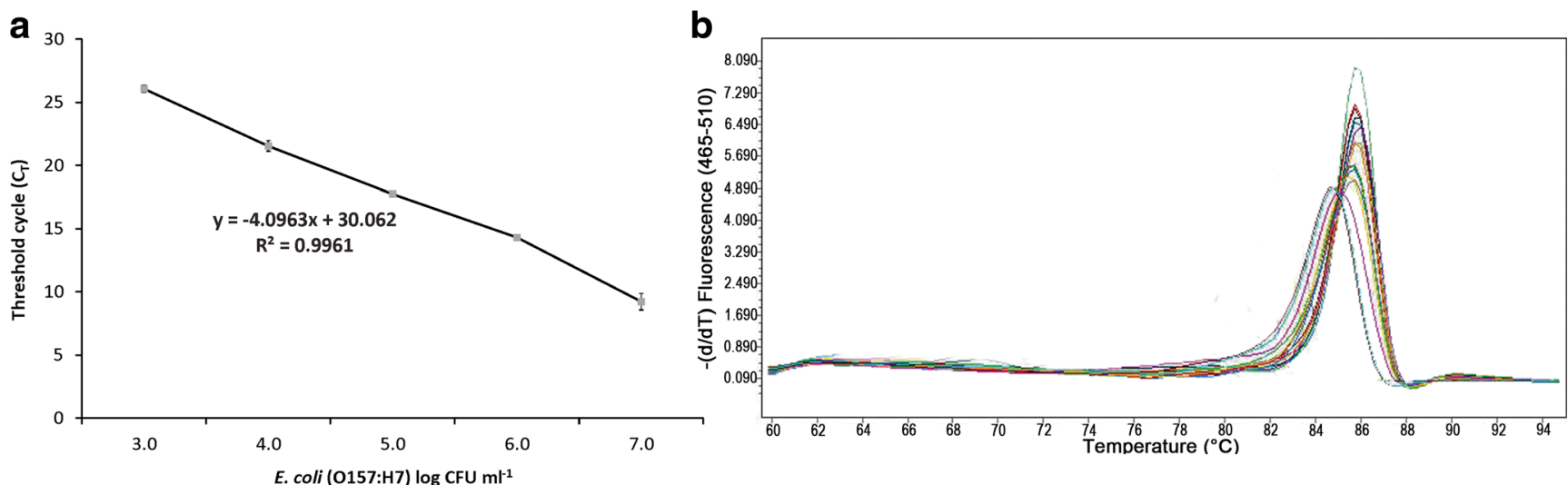

Fig. 1 a qPCR standard curve for $E$. coli O157:H7 generated by plotting the $C_{\mathrm{T}}$ number against $\mathrm{CFU} / \mathrm{mL}$ of the culture. Error bar indicates the standard error of three independent replicates. b Melt curve analysis of qPCR products 
Fig. 2 Quantification of Shiga-like toxin-producing $E$. coli by qPCR in fresh vegetables (a), rhizosphere soils (b), and water used for irrigation and processing (c) Means of three replicate values plotted, error bars indicate the standard error.

Values followed by the same letter in each panel are not significantly different from each other as determined by DMRT $(p \leq 0.05)$
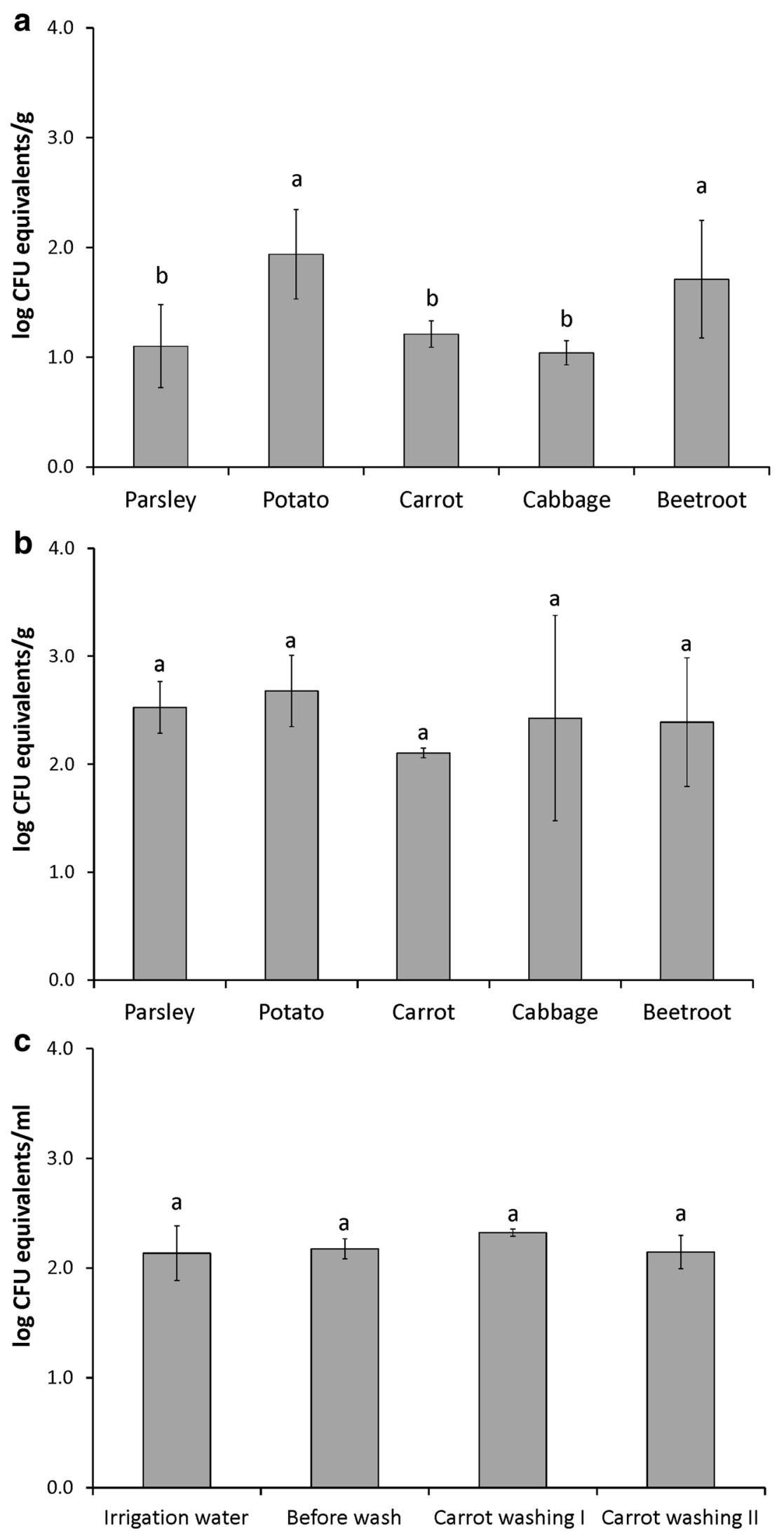


\section{Discussion}

Escherichia coli O157:H7 contamination being an omnipresent foodborne pathogen has caused multitude health issues and mortality due to enterohemorrhagic colitis which was recognized two to three decades ago (Armstrong et al. 1996; Alegbeleye et al. 2018). Despite precautionary measures being strictly followed in developed countries to produce O157free vegetables and fruits, developing countries like India lack focus in such aspects. In this study, we have surveyed the prevalence of $E$. coli $\mathrm{O} 157: \mathrm{H} 7$ in the list of vegetables preferred for raw consumption that are produced at Nilgiri Mountains and supplied to many parts of south India. Earlier, Sehgal et al. (2008) had reported an increase in E. coli $\mathrm{O} 157: \mathrm{H} 7$ population across India during a period of 10 years and pointed out the contribution of animal and water sources in disseminating the same. In the current investigation, we have confirmed that fresh vegetables of the locality were highly prone to $E$. coli $\mathrm{O} 157: \mathrm{H} 7$ from soil and irrigated water. The physicochemical properties of soils measured in the present survey suggested that these soils are conducive for long-term survival of $E$. coli $\mathrm{O} 157: \mathrm{H} 7$ (> 75 days) (Naganandhini et al. 2015).

The World Health Organization (WHO) declared complete destruction of E. coli $\mathrm{O} 157: \mathrm{H} 7$ only when entire food is cooked at $70{ }^{\circ} \mathrm{C}$ (http://www.who.int/news-room/fact-sheets/ detail/e-coli). The issue remains unresolved when vegetables are freshly consumed as salads and fast foods (carrot, cabbage, onion etc.) and used for garnishing (coriander, parsley etc.) (Abdul-Raouf et al. 1993; Sharapov et al. 2016). Our study was focused on such vegetables and total coliforms and E.coli loads were higher in rhizosphere soil compared to vegetables collected from the same field (Tables 2 and 3 of the present study). This indicated that soil acting as a source of contamination may be at the time of conventional harvest and piling up of vegetables at the field before transport. Most interestingly, there was no prevalence of $E$. coli in parsley herb while its rhizosphere soil had higher count $\left(4.05 \pm 0.18 \log\right.$ CFU g ${ }^{-}$ $\left.{ }^{1}\right)$. Several factors can affect bacterial survival on fruits and vegetables at the pre-harvest stage, including UV exposure (Muela et al. 2000; Steele et al. 2005), temperature (Han and Linton 2004), produce surface drying (Steele et al. 2005), and antimicrobial activity (Hashem and Saleh 1999). The antimicrobial activity associated with the high ferrous sequestering nature of stem extracts of parsley inhibited $E$. coli (Wong and Kitts 2006; Petrolini et al. 2013). Moreover, soil dehydrogenase activity directly correlated with $E$. coli load since both were recorded highest in parsley and lesser in cabbage rhizosphere soil (Tables 1 and 4). In accordance with total coliforms and $E$. coli, percentage occurrence of $\mathrm{O} 157: \mathrm{H} 7$ was significantly higher in rhizosphere soil (1.6 to $42.5 \%$ ) compared to that of vegetables collected ( 0.9 to $5.8 \%$ ) (Table 5) which confirmed generic $E$. coli to be the indicator for the 0157 :
$\mathrm{H} 7$ occurrence. Further, the persistence of E. coli $\mathrm{O} 157: \mathrm{H} 7$ in agricultural soils poses a major threat to fresh vegetables cultivated in that locality (Naganandhini et al. 2015). The factors such as application of pre-matured compost (Mukherjee et al. 2007), contaminated manure and irrigation water (Solomon et al. 2002; Islam et al. 2004), inorganic fertilizer amendment (Franz et al. 2008), and non-sanitized wash water (Gil et al. 2009) were so far reported to contribute for abundance of $\mathrm{O} 157: \mathrm{H} 7$ in vegetables. In the present study, we have quantified the presence of $E$. coli $\mathrm{O} 157: \mathrm{H} 7$ in both irrigation and wash water used in that locality. The count of O157:H7 was detected higher in wash water used for carrot processing and the count gets even higher after wash (Table 5). This may lead to more hazardous effects as the same water is being reused for washing the next slot leading to a heavy buildup of inoculum in carrot samples after processing. The carrot being the highly preferred raw vegetable in that locality has also emerged as a vehicle of $\mathrm{O} 157: \mathrm{H} 7$ transmission to humans due to unhygienic conventional cultivation and processing.

qPCR is considered as a method of choice for the detection and quantification of microorganisms (Postollec et al. 2011). qPCR of vegetable samples is superior for detecting pathogenic E. coli over conventional cultural and serological techniques (Liming and Bhagwat 2004). The predominance of STECtype carrying stx 1 sequences in some vegetables, such as carrot, parsley, which are consumed raw, represents a serious risk to public health. The presence of eaeA in STEC seropathotypes O157 and O157:H7 was reported in cattle, cattle carcasses, and environmental samples in Istanbul by multiplex PCR (Yilmaz et al. 2006). In the same way, stxl was used a as marker to detect STEC using qPCR in the current work and highly virulent $\mathrm{O} 157: \mathrm{H} 7$ were identified in all the samples considered (carrot beetroot, potato, cabbage, and parsley).

To conclude, the study described the source of entry of E. coli $\mathrm{O} 157: \mathrm{H} 7$ contamination in a fresh vegetable production system of South India. The results indicate that most of the fresh vegetables growing in this locality can mediate O157:H7-based foodborne illness through soil and water contamination. Scientific attention regarding sanitized wash water and hygienic cultivation practices in such localities, which act as a hub for fresh vegetable supply, would help prevent loss of human life due to STEC infection. Hence, providing knowledge-based agricultural production system to the farmers and developing strategies to minimize the foodborne illness in farm to fork approach are necessary in order to ensure the safety of fresh produce delivering to the consumers.

Funding This work was supported by Department of Biotechnology, New Delhi through R \& D Project (Molecular detection and quantification of Shiga-like toxin-producing Escherichia coli in fresh vegetables, sanction no. BT/PR10398/PFN/20/899/2013). 


\section{Compliance with ethical standards}

Conflict of interest The authors declare that they have no conflict of interest.

Research involving human participants and/or animals N/A

Informed consent N/A

\section{References}

Abdul-Raouf UM, Beuchat LR, Ammar MS (1993) Survival and growth of Escherichia coli $\mathrm{O} 157: \mathrm{H} 7$ on salad vegetables. Appl Environ Microbiol 59:1999-2006

Alegbeleye OO, Singleton I, Sant'Ana AS (2018) Sources and contamination routes of microbial pathogens to fresh produce during field cultivation: a review. Food Microbiol 73:177-208. https://doi.org/ 10.1016/j.fm.2018.01.003

Armstrong GL, Hollingsworth J, Morris JG Jr (1996) Emerging foodborne pathogens: Escherichia coli O157: H7 as a model of entry of a new pathogen into the food supply of the developed world. Epidemiol Rev 18:29-51

Cardamone C, Aleo A, Mammina C, Oliveri G, Di Noto AMJ (2015) Assessment of the microbiological quality of fresh produce on sale in Sicily, Italy: preliminary results. J Biol Res 22:3. https://doi.org/ 10.1186/s40709-015-0026-3

CDC (2018) Food safety: food borne illness and germs. https://www.cdc. gov/foodsafety/foodborne-germs.html

Cebula TA, Payne WL, Feng P (1995) Simultaneous identification of strains of Escherichia coli serotype 0157:H7 and their Shiga-like toxin type by mismatch amplification mutation assay-multiplex PCR. J Clin Microbiol 33:248-250

Delannoy S, Beutin L, Fach P (2013) Towards a molecular definition of enterohemorrhagic Escherichia coli (EHEC): detection of genes located on $\mathrm{O}$ island 57 as markers to distinguish EHEC from closely related enteropathogenic E. coli strains. J Clin Microbiol 51:10831088. https://doi.org/10.1128/jcm.02864-12

Denis N, Zhang H, Leroux A, Trudel R, Bietlot H (2016) Prevalence and trends of bacterial contamination in fresh fruits and vegetables sold at retail in Canada. Food Control 67:225-234. https://doi.org/10. 1016/j.foodcont.2016.02.047

Fode-Vaughan KA, Maki JS, Benson JA, Collins MLP (2003) Direct PCR detection of Escherichia coli O157:H7. Lett Appl Microbiol 37:239-243. https://doi.org/10.1046/j.1472-765X.2003.01386.x

Franz E, Semenov AV, Termorshuizen AJ, De Vos OJ, Bokhorst JG, Van Bruggen AHC (2008) Manure-amended soil characteristics affecting the survival of E. coli O157:H7 in 36 Dutch soils. Environ Microbiol 10:313-327. https://doi.org/10.1111/j.1462-2920.2007.01453.x

Franz E et al (2014) Exploiting the explosion of information associated with whole genome sequencing to tackle Shiga toxin-producing Escherichia coli (STEC) in global food production systems. Int J Food Microbiol 187:57-72. https://doi.org/10.1016/j.ijfoodmicro. 2014.07.002

Gil MI, Selma MV, López-Gálvez F, Allende A (2009) Fresh-cut product sanitation and wash water disinfection: problems and solutions. Int J Food Microbiol 134:37-45. https://doi.org/10.1016/j.ijfoodmicro. 2009.05.021

Gutiérrez-Rodríguez E, Gundersen A, Sbodio A, Koike S, Suslow TV (2019) Evaluation of post-contamination survival and persistence of applied attenuated E. coli $\mathrm{O} 157: \mathrm{H} 7$ and naturally-contaminating E. coli $\mathrm{O} 157: \mathrm{H} 7$ on spinach under field conditions and following postharvest handling. Food Microbiol 77:173-184. https://doi.org/ 10.1016/j.fm.2018.08.013
Han Y, Linton RH (2004) Fate of Escherichia coli O157:H7 and Listeria monocytogenes in strawberry juice and acidified media at different $\mathrm{pH}$ values and temperatures. J Food Prot 67:2443-2449. https://doi. org/10.4315/0362-028x-67.11.2443

Hashem FA, Saleh MM (1999) Antimicrobial components of some cruciferae plants (Diplotaxis harra Forsk. and Erucaria microcarpa Boiss.). Phytother Res 13:329-332. https://doi.org/10.1002/(SICI) 1099-1573(199906)13:4<329::AID-PTR458>3.0.CO;2-U

Heredia N, García S (2018) Animals as sources of food-borne pathogens: a review. Anim Nutr 4:250-255. https://doi.org/10.1016/j.aninu. 2018.04.006

Hines E (2000) PCR-based testing: unraveling the mystery. Food Qual 7: $22-28$

Ibekwe AM, Watt PM, Shouse PJ, Grieve CM (2004) Fate of Escherichia coli $\mathrm{O} 157: \mathrm{H7}$ in irrigation water on soils and plants as validated by culture method and real-time PCR. Can J Microbiol 50:1007-1014. https://doi.org/10.1139/w04-097

Islam M, Doyle MP, Phatak SC, Millner P, Jiang X (2004) Persistence of Enterohemorrhagic Escherichia coli $\mathrm{O} 157: \mathrm{H} 7$ in soil and on leaf lettuce and parsley grown in fields treated with contaminated manure composts or irrigation water. J Food Prot 67:1365-1370. https://doi.org/10.4315/0362-028X-67.7.1365

Jenkinson DS, Ladd JN (1981) Microbial biomass in soil, measurement and turn over. In: Paul EA, Ladd JN (eds) Soil biochemistry volume 5. Marcel Dekker, New York, pp 415-471

Julien-Javaux F, Gérard C, Campagnoli M, Zuber S (2019) Strategies for the safety management of fresh produce from farm to fork. Curr Opin Food Sci. https://doi.org/10.1016/j.cofs.2019.01.004

Karmali MA (2004) Infection by shiga toxin-producing Escherichia coli. Mol Biotechnol 26:117-122. https://doi.org/10.1385/mb:26:2:117

Kennedy M et al (2004) Hospitalizations and deaths due to Salmonella infections, FoodNet, 1996-1999. Clin Infect Dis 38:S142-S148. https://doi.org/10.1086/381580

Kim J-H, Rhim S-R, Kim K-T, Paik H-D, Lee J-Y (2014) Simultaneous detection of Listeria monocytogenes, Escherichia coli O157:H7, Bacillus cereus, Salmonella spp., and Staphylococcus aureus in low-fatted milk by multiplex PCR. Korean J Food Sci Anim Resour 34:717-723. https://doi.org/10.5851/kosfa.2014.34.5.717

Klein D, Loh T, Goulding R (1971) Rapid procedure to evaluate the dehydrogenase activity of soils low in organic matter. Soil Biol Biochem 3: 385-387. https://doi.org/10.1016/0038-0717(71)90049-6

Liming SH, Bhagwat AA (2004) Application of a molecular beaconreal-time PCR technology to detect Salmonella species contaminating fruits and vegetables. Int J Food Microbiol 95:177-187. https:// doi.org/10.1016/j.ijfoodmicro.2004.02.013

Mackay IM (2004) Real-time PCR in the microbiology laboratory. Clin Microbiol Infect 10:190-212. https://doi.org/10.1111/j.1198-743X. 2004.00722.x

Malorny B, Tassios PT, Rådström P, Cook N, Wagner M, Hoorfar J (2003) Standardization of diagnostic PCR for the detection of foodborne pathogens. Int J Food Microbiol 83:39-48. https://doi. org/10.1016/S0168-1605(02)00322-7

Mckillip JL, Drake M (2004) Real-time nucleic acid-based detection methods for pathogenic bacteria in food. J Food Prot 67:823-832. https://doi.org/10.4315/0362-028x-67.4.823

Muela A, García-Bringas JM, Arana I, Barcina I (2000) The effect of simulated solar radiation on Escherichia coli: the relative roles of UV-B, UV-A, and photosynthetically active radiation. Microb Ecol 39:65-71. https://doi.org/10.1007/s002489900181

Mukherjee A, Speh D, Diez-Gonzalez F (2007) Association of farm management practices with risk of Escherichia coli contamination in pre-harvest produce grown in Minnesota and Wisconsin. Int $\mathbf{J}$ Food Microbiol 120:296-302. https://doi.org/10.1016/j. ijfoodmicro.2007.09.007

Naganandhini S, Kennedy ZJ, Uyttendaele M, Balachandar D (2015) Persistence of pathogenic and non-pathogenic Escherichia coli 
strains in various tropical agricultural soils of India. PLoS One, e0130038 10. https://doi.org/10.1371/journal.pone.0130038

NHB (2017) National horticultural board: annual report. Ministry of Agriculture, India

NIN (2011) Dietary guidelines for indians. National Institute Of Nutrition, Hyderabad

O'Grady J, Ruttledge M, Sedano-Balbás S, Smith TJ, Barry T, Maher M (2009) Rapid detection of Listeria monocytogenes in food using culture enrichment combined with real-time PCR. Food Microbiol 26:4-7. https://doi.org/10.1016/j.fm.2008.08.009

Olaimat AN, Holley RA (2012) Factors influencing the microbial safety of fresh produce: a review. Food Microbiol 32:1-19. https://doi.org/ 10.1016/j.fm.2012.04.016

Olsen SJ, MacKinnon LC, Goulding JS, Bean NH, Slutsker L (2000) Surveillance for foodborne-disease outbreaks-United States, 1993-1997. MMWR CDC Surveill Summ 49:1-62

Petrolini FVB, Lucarini R, Souza MG, Pires RH, Cunha WR, Martins CHG (2013) Evaluation of the antibacterial potential of Petroselinum crispum and Rosmarinus officinalis against bacteria that cause urinary tract infections. Braz J Microbiol 44:829-834

Postollec F, Falentin H, Pavan S, Combrisson J, Sohier D (2011) Recent advances in quantitative PCR (qPCR) applications in food microbiology. Food Microbiol 28:848-861. https://doi.org/10.1016/j.fm. 2011.02.008

Sehgal R, Kumar Y, Kumar S (2008) Prevalence and geographical distribution of Escherichia coli O157 in India: a 10-year survey. Trans R Soc Trop Med Hyg 102:380-383. https://doi.org/10.1016/j.trstmh. 2008.01.015

Sharapov UM et al (2016) Multistate outbreak of Escherichia coli O157: $\mathrm{H} 7$ infections associated with consumption of fresh spinach: United States, 2006. J Food Prot 79:2024-2030. https://doi.org/10.4315/ 0362-028x.Jfp-15-556

Smith JL, Fratamico P (2005) Diarrhea-inducing Escherichia coli. In: Fratamico PM, Bhunia AK, Smith JL (eds) Foodborne pathogens: microbiology and molecular biology. Caister Academic Press, Norfolk, pp 357-382

Söderström A et al (2008) A large Escherichia coli O157 outbreak in Sweden associated with locally produced lettuce. Foodborne Pathog Dis 5:339-349. https://doi.org/10.1089/fpd.2007.0065

Solomon EB, Yaron S, Matthews KR (2002) Transmission of Escherichia coli $\mathrm{O} 157: \mathrm{H} 7$ from contaminated manure and irrigation water to lettuce plant tissue and its subsequent internalization. Appl Environ Microbiol 68:397-400. https://doi.org/10.1128/AEM.68.1. 397-400.2002

Steele M, Mahdi A, Odumeru J (2005) Microbial assessment of irrigation water used for production of fruit and vegetables in Ontario, Canada. J Food Prot 68:1388-1392. https://doi.org/10.4315/0362-028x-68.7.1388

$\mathrm{Su} \mathrm{XL}, \mathrm{Li}$ Y (2005) Surface plasmon resonance and quartz crystal microbalance immunosensors for detection of Escherichia coli O157:H7. TransASAE 48:405-413. https://doi.org/10.13031/2013.17919

Wendel AM et al (2009) Multistate outbreak of Escherichia coli O157:H7 infection associated with consumption of packaged spinach, August-September 2006: the Wisconsin investigation. Clin Infect Dis 48:1079-1086. https://doi.org/10.1086/597399

Wong PYY, Kitts DD (2006) Studies on the dual antioxidant and antibacterial properties of parsley (Petroselinum crispum) and cilantro (Coriandrum sativum) extracts. Food Chem 97:505-515. https:// doi.org/10.1016/j.foodchem.2005.05.031

XLSTAT (2010) XLSTAT. Addinsoft SARL, Paris http://www.xlstat.com

Yilmaz A, Gun H, Ugur M, Turan N, Yilmaz H (2006) Detection and frequency of VT1, VT2 and eaeA genes in Escherichia coli O157 and $\mathrm{O} 157: \mathrm{H} 7$ strains isolated from cattle, cattle carcasses and abattoir environment in Istanbul. Int J Food Microbiol 106:213-217. https://doi.org/10.1016/j.ijfoodmicro.2005.05.018

Publisher's note Springer Nature remains neutral with regard to jurisdictional claims in published maps and institutional affiliations. 